\title{
Educational Philosophy of Swami Vivekananda
} VIKRANT MISHRA

\begin{abstract}
Swami Vivekananda has said that education is the manifestation of the perfection already present in man. Through Vivekananda's life experiences, he learned many truths and shared them with others. These truths addressed the subject of education. To him education played and plays a vital role in curing the evils in society, and it is critical in shaping the future of humanity. He talked about "man-making" education. In Vivekananda's educational scheme for India, the uplift of women and the masses received the highest priority. In this paper, a systematic attempt has been to explain the educational philosophy of Swami Vivekananda.
\end{abstract}

Keywords: Swami Vivekananda and Education philosophy

The great contribution of Swami Vivekananda was to build a bridge between Indian culture and Western culture. He did it by interpreting Hindu scriptures and philosophy and the Hindu way of life and institutions to the Western people in a format which they could understand. He made the Western people realize that they could learn much from Indian spirituality for sake of their own wellbeing and development as human beings. $\mathrm{He}$ showed that, in spite of her poverty and backwardness, India had a great contribution to make to world culture. In this way Vivekananda was somewhat instrumental in ending India's cultural isolation from the rest of the world. $\mathrm{He}$ was India's first great cultural ambassador to the West.

In addition, Swamiji's interpretation of ancient Hindu scriptures, philosophy, institutions, etc helped to prepare the Indian mind to accept and apply in practical life the two best elements of Western culture, namely science/technology and humanism. Swamiji taught Indians how to master Western science and technology, and, at the same time, develop spiritually. Swamiji also taught Indians how to adapt Western humanism (especially the ideas of individual freedom, social equality and justice and respect for women) to the Indian ethos. Swami Vivekananda's great educational philosophy seems to be utmost relevant in the today's world. Although Vivekananda did not write a book on education, he contributed valuable thoughts on the subject that are still relevant and viable today in a whole host of educational venues.

\section{Swami Vivekananda's Concept of Education}

Swami Vivekananda understood that he was one who had experienced in his own life all the truths about which he spoke. He was able to learn from these experiences and share wisdom with others with regards to education. For him, education played a vital role in curing the evils in society, and it is critical in shaping the future of humanity. In order to understand his thoughts, we should first consider his oft-quoted definition of education:

- "Education is the manifestation of the perfection already in man" (Complete Work of Swami Vivekanand (CW), vol. IV, p. 358).

Vivekananda's definition of education is one of remarkable insight. First of all, the word "manifestation" can imply that something already exists and is waiting to be expressed. The main focus in learning is to make the hidden ability of a learner manifest in this reality. As Vivekananda said, "What a man 'learns" is really what he 
'discovers,' by taking the cover off his own soul, which is a mine of infinite knowledge" (CW, vol. I, p. 28). According to the Vedanta philosophy, knowledge is inherent in a human being, like a spark in a piece of flint. All that is needed is the strike of suggestion to bring it out. "Manifestation" indicates spontaneous growth, provided that the impediments, if any, are removed.

Next importance in the Swami's definition of education is the expression that it is already in man. This refers to a human being's potential, which is the range of the abilities and talents, known or unknown that he or she was born with. "Potential" speaks of the possibility of awakening something that is lying dormant. Israel Scheffler, in his book of Human Potential, considered three aspects of the idea of 'Potential': (i) the capacity to acquire a specific characteristic or to become someone who possesses it. For instance, we might say, 'Amal has the capacity to become a Maradona, the world-famous soccer player'; (ii) the propensity - an attribute which indicates what a person is likely to do when the opportunity comes and freedom of choice is available. It suggests something about a person's motivation. For example, Rabindranath Tagore's propensity, expressed in his Gitanjali, indicates his strong aspiration to discover the wonder behind this creation; and (iii) the capability - i.e. a person's motivation and efficiency in working towards an intended outcome. It refers to something more than a person's capacity to perform. Rather, it is a person's strength and capacity to get rid of obstacles to his learning. For example, these obstacles might include a lack of motivation or the roadblocks in a person's environment.

Thus, these three concepts - capacity, propensity, and capability - emphasize three aspects of education, respectively: (i) that which makes learning possible; (ii) the development of learning; and (iii) self-development or selfempowerment. A child has many potentials of variable worth, and these many potentials may create mental conflict within him. The mental conflict may have to do with the overwhelming number of choices available to him, or "roads" to take. Therefore, he has to learn to choose which one or ones he should try to develop, and which ones he should minimize, counter or ignore. Then again, as his chosen potentials start to unfold, these choices should be supervised in order to achieve their harmonious and purposeful development.

The word "perfection" in the Swami's definition of education is also very significant. We can see that every act connected with learning, training, etc., is part of a process directed towards an end. The English word 'perfect' implies completion, or something being made whole. The Greek word teleics is translated as "perfect," and suggests the idea of attaining a goal or an end. Drawing on these meanings, one may conclude that perfection in educational parlance is the goal of actualizing the highest human potential.

The goal of education - general or ultimate - is essentially laid down by society and therefore varies from society to society (Aggarwal, 2002). Even as every society tries to keep pace with the contemporary world, societies, such as Indian society, ones with a stable and older tradition cherish some higher goals of everlasting value. Taking into consideration the vast experience of the Indian civilization, Vivekananda's use of the word 'perfection' needs to be viewed at two levels:

(1). 'Perfection' in the metaphysical sense implies the realization of the soul's own ever perfect nature. The Vedanta philosophy says that a human being is not born a sinner, nor is he necessarily a victim of circumstances. The main cause of his suffering is his ignorance of his true nature. Explaining the implications of this, Vivekananda once said: 'The Light Divine within is obscured in most people. It is like a lamp in a cask of iron, no gleam of light can shine through. 
Gradually, by purity and unselfishness, we can make the obscuring medium less and less dense, until at last it becomes transparent as glass." (CW, vol. VII, p. 21)

(2). At the empirical level the concept of "perfection" has to address the various problems human beings encounter in society. As Vivekananda said: "The education which does not help the common mass of people to equip themselves for the struggle for life, which does not bring out strength of character, a spirit of philanthropy, and the courage of a lion - is it worth the name? Real education is that which enables one to stand on one's own legs." (CW, vol. VII, pp. 147-148)

"Education," he said, must provide 'lifebuilding, man-making, character-making assimilation of ideas." (CW, vol. III, p. 302) The ideal of this type of education would be to produce an integrated person - one who has learned how to improve his intellect, purify his emotions, and stand firm on moral virtues and unselfishness. There are two levels designated by the ancient Indian scriptures as para vidya (spiritual values) and apara vidya (secular values) respectively. This division is merely for practical convenience; otherwise vidya, or learning, is a continuum, leading one towards the ultimate goal which, according to Vivekananda, was complete freedom of the soul.

Vivekananda also observed that, if education is to serve the entire human being, in all his/her dimensions, the pursuit of knowledge will be a lifelong process. Even an illustrious being like Sri Ramakrishna said, from his own experience, "As long as I live, so long do I learn." At the empirical level, today's knowledge explosion can keep people engaged for their entire lives. Therefore, education must be considered a continuous and lifelong process. So far, our discussion of Vivekananda's ideas on education has been a simplistic analysis centering on his definition of education. However, this fails to do justice to some of his ideas on related issues, such as the relationship between education and society, between education and the teacher, between the professed goals of education and the goals actually achieved, and so forth. It is apparent, therefore, that Vivekananda's deep concern for social justice has not been reflected so far in our definition. To this end, we can probe further into the expressions "manifestation" and "already in man," bearing in mind the situation in India in those days.

In explaining the term "manifestation," the Swami quoted part of one of the yoga aphorisms of Patanjali (author of an ancient Indian scripture 4/3) - Tatah kshetrikavat [Therefore the obstructions] - that is to say, just as a farmer breaks the barriers to a course of water, which thereafter flows by its own force to irrigate his fields, so also a person's inherent power will spontaneously manifest itself when external and internal obstacles, if any, are removed at the proper time by the teachers or the education system. Such obstacles are of various kinds. External obstacles might be in the form of unfair distribution of educational resources and opportunities, inequalities in economic development and socio-political instability; whereas internal obstacles might have to do with the dynamics of the education system, such as the teacher/student relationship, the student's capacity to make personal judgments or to adapt to changes, and the student's mental or physical capacities.

In order to tackle these obstacles, the education system should take on two responsibilities: (i) it should help a person build a healthy and dynamic frame of mind to enable him to meet the challenges of life; and (ii) it should try to prevent, through proper training of its present students, any future evils in people and society which are likely to further complicate the problems of human beings. At the same time, however, the teachers and the designers of education systems must always keep in mind the 
Vedantic idea that whatsoever good or bad impressions a mind carries, a human being is essentially pure and divine, and a repository of immense possibilities.

In Vivekananda's view, educational concerns related to a person's interaction with society should receive due attention. The purpose of society is to help secure the well-being of human beings. In reality, however, human beings frequently find themselves entrapped in a society that threatens their freedom. Freedom, Vivekananda expounds, is essential for a person's educational growth. An ideal society, according to Vivekananda, should provide the resources as well as the opportunity for each of its members to develop his or her potential to the maximum. Education must embrace the whole society, with special attention to those who are most in need of it and who, for one reason or another, are unable to avail themselves of the existing facilities.

\section{The Mind Needs Proper Training}

Vivekananda concurred with contemporary thinkers when he asserted that the mind - the chief instrument of learning - deserves more attention than it had earlier received. Training the mind should be a student's highest priority, and not simply the accumulation, the memorizing and the repeating of facts. In the long run, stuffing one's mind with information, technical skills and useless trivia only creates more problems if one's mind is not nourished and strengthened and made healthy. Vivekananda's message is very timely to the information-saturated society we live in today where people tend to know more but understand less of what they know. Training of the mind in all its aspects is conspicuously absent in today's education. Learning to concentrate the mind was the focus in the Swami's scheme. He said: "To me the very essence of education is concentration of mind, not the collecting of facts" (CW, vol. VI, p. 38). In doing anything - such as thinking, working with one's hands, etc. - the better the power of concentration the better the outcome will be. And this power of keeping the mind on the task can be improved. Training the mind to concentrate on a specific subject has several stages, the primary one being learning how to collect the mind and preventing it from running hither and thither. The student trains his mind to be more attentive and more "mindful."

Next, the student must learn how to detach his mind from distractions that impose themselves in spite of himself. Then, simultaneously, he must direct the mind onto the desired subject and focus the full force of his mind on it. To give an example: a convex lens gathers sunlight and focuses it on one point to burn a piece of paper. Likewise, when a mind becomes concentrated, it acquires tremendous power and is able to unlock the mysteries of the subject it is focused upon.

Similarly, the Swami also wanted students to cultivate willpower. According to him, willpower is developed when "the current and expression of will are brought under control and become fruitful."(CW, vol. IV, p. 490) Willpower is necessary not only to conduct the learning process, but also to strengthen one's character.

\section{Relationship of Culture and Education in Terms of Swami Vivekananda}

Every society has its outer aspect called "civilization," and also its inner aspect called "culture." In both of these a child is moulded and educated so that the beliefs and practices of his forefathers are carried on and not forgotten (Chakarborty, 2004). Nevertheless, as Vivekananda says: "It is culture that withstands shocks, not a simple mass of knowledge. Knowledge is only skin-deep, as civilisation is, and a little scratch brings out the old savage." (CW, vol. III, p. 291)

A society is forever adding to its learning and culture. To the brilliant mind of T.S. Eliot, education was but a manifestation of culture. He said, "The purpose of education, it seems, is to 
transmit culture: so culture is likely to be limited to what can be transmitted by education."

Similarly, Vivekananda observed that, through education, a child learns a culture and his behaviour is moulded accordingly. $\mathrm{He}$ is thus guided towards his eventual role in society. In this process, several agents - such as his parents, peers and teachers - assist him. But nowadays, as formal education has become more and more institutionalized, teachers are expected to play a more significant role. A teacher needs to help a student learn how to think, what to think, how to discriminate, and how to appreciate things. This is not just a matter of intellectual manipulation. This kind of teaching requires moral conviction and the courage to continuously pursue one's own course at all costs. The teacher must not only possess the knowledge he is to transmit to the student, but he must also know how to transmit it. And, in addition to the content of the teaching, what the teacher gives or transfers, to be truly effective, must possess some other qualities. For instance, the teacher should share with the student the conviction that they are both truly one in Spirit at the same time cultivating in the student a feeling of dignity and self-respect. As Vivekananda said: "The only true teacher is he who can immediately come down to the level of the student, and transfer his soul to the student's soul and see through the student's eyes and hear through his ears and understand through his mind. Such a teacher can really teach and none else." (CW, vol. IV, p. 183)

In a favourable ambience such as this "the process of uncovering" the veil of ignorance works smoothly (CW, vol. I, p. 28). On the student's side, in order to facilitate the manifestation of his innate strength and knowledge, he should cultivate the spirit of shraddha - that is, faith in himself, humility, submission, and veneration for the teacher. This is also necessary to create a

Favourable environment for learning. The Taittiriya Upanishad (an ancient Indian scripture -
1.11.2) gives the instruction: "Acharyadevo bhava - Let the teacher be your deva" [i.e. a person fit to be worshipped or highly honoured]. The teacher/pupil relationship, based on respect and mutual trust, is the cornerstone of the edifice of Vivekananda's scheme of education. The Upanishads also advocated this. Before starting the lesson, the teacher and the pupils were to pray together so that they would mutually benefit and be strengthened by the teaching/learning process.

\section{Main Objective of Education is Character Building}

Swami Vivekananda has said that chastity is the first virtue in man or woman, and the man who, however he may have strayed away, cannot be brought to the right path by a gentle and loving and chaste wife is indeed very rare. The world is not yet as bad as that. We hear much about brutal husbands all over the world and about the impurity of men, but is it not true that there are quite as many brutal and impure women as men? If all women were as good and pure as their own constant assertions would lead one to believe, I am perfectly satisfied that there would not be one impure man in the world. What brutality is there which purity and chastity cannot conquer? A good, chaste wife, who thinks of every other man except her own husband as her child and has the attitude of a mother towards all men, will grow so great in the power of her purity that there cannot be a single man, however brutal, who will not breathe an atmosphere of holiness in her presence. [As a woman, I find this offensive. You are saying it is the woman's fault for the brutality of men.] Similarly, every husband must look upon all women, except his own wife, in the light of his own mother or daughter or sister. That man, again, who wants to be a teacher of religion must look upon every woman as his mother, and always behave towards her as such.

Vivekananda's guru, Sri Ramakrishna, used to say that manush needs to become man- 
hush - that is, a man needs to become a true man. "He alone is a man," he said, "whose spiritual consciousness has been awakened," (Vivekananda, 2008) Following his Master, Vivekananda emphasized that "the ideal of all education, all training, should be this man-making'. Lamenting over the prevailing system of education, he said: But, instead of that, we are always trying to polish up the outside. What use in polishing up the outside when there is no inside? The end and aim of all training is to make the man grow." (CW, vol. II, p. 15)

In order to rectify the defects in the existing system, man's limited view of himself, on which the existing system of education is based, needs to be reconsidered. A human being is not simply a composite of body and mind. $\mathrm{He}$ is something more ((Krishnamurti, 1912). According to the Vedanta philosophy, a human being has five sheaths, or coverings: the physical sheath, the vital sheath, the mental sheath, the intellectual sheath, and the blissful sheath. Today's education can at best touch the first four sheaths, but not the last one. Secular knowledge, skills and moral values may take care of the first four sheaths, but spiritual knowledge is essential for the fifth. Moreover, it should be noted that the fifth sheath is the reservoir of bliss, knowledge and strength, and all the other sheaths are activated by the fifth.

There is no doubt that today's education neglects training of the mind in all its aspects, but it also neglects the spiritual side of the human being. People's minds are not directed to higher pursuits of life with the result that their hidden potentials are not revealed. Only when wisdom, peace, strength, unselfishness, loving concern for others and other virtues become evident is a person transformed from a sensuous being to a true human being (Gambhirananda, 1996).

A tremendous explosion of knowledge without commensurate wisdom, plus immense power not tempered with discrimination, have made education today a potential source of danger.
This is a serious problem looming large on humanity's horizon. As Vivekananda observed: Intellect has been cultured with the result that hundreds of sciences have been discovered, and their effect has been that the few have made slaves of the many - that is all the good that has been done. [Fix errors in these sentences] Artificial wants and desires have been created; and every poor man, whether he has money or not, desires to have those wants satisfied, and when he cannot, he struggles, and dies in the struggle (CW, vol. I, p. 414). In order to counterbalance this uneven development, Vivekananda strongly recommended the adoption of a "spiritual and ethical culture," and he looked upon "religion as the innermost core of education," (CW, vol. III, p. 182; vol. V, p. 231). But by "religion" he did not mean any particular religion. Religion to him meant the true eternal principles that inspire every religion. This is what touches the heart and has the potential to affect desirable changes in one's motivation. It also gives mental strength and broadness of outlook. Discussing the practical implications of morality, Swami Vivekananda once observed: "What is meant by morality? Making the subject strong by attuning it to the Absolute, so that finite nature ceases to have control over us."(CW, vol. II, p. 137)

Thus, in order to be worthwhile and effective, education must be rooted in in the science of spirituality, and evidently not in dogma. Character-building was fundamental in Vivekananda's educational scheme, as against career-orientation, which occupies centre-stage in today's education. A person is what his thoughts have made him. Explaining this, the Swami said, "Each thought is a little hammer blow on the lump of iron which our bodies are, manufacturing out of it what we want it to be." (CW, vol. VII, p. 20) That is why one finds that the focus of the Swami's educational thoughts was on assimilation of man-making, or character building ideas. 
Everything a person does, every thought, every move, leaves an impression on the mind. Even when it is not outwardly apparent, it is strong enough to work beneath the surface. A person's character is determined by the sum total of these impressions. When a large number of these impressions come together, they form a habit. A habit then becomes a powerful force, for character is but repeated habits. This is why, through the acquisition and repetition of desirable habits, one's character can be remodeled. The people one associates with, good or bad, contribute much to the development of one's character. In fact, their impact is greater than that of didactic teaching. That is why Swami Vivekananda said: "Words, even thoughts, contribute only one-third of the influence in making an impression, the man, twothirds," (CW, vol. II, p. 14). He therefore desired that the teacher's life and personality should be like a blazing fire which could have a positive influence on the pupils in his care. Exposure to exemplary role models, particularly when they are teachers, and also to wholesome curriculum materials that impart culturally-approved values to the young, are critical to character education.

Character-building education might focus on teaching what is right and wrong. But simultaneously, or alternatively, it should teach how to decide what is right and wrong. It has been rightly argued that participation in discussions of morality is more instructive than simply hearing about it. In any case, however, the teachers should be moral exemplars if the classroom and the school are to serve as arenas for the teaching of ethics. The students then have the experience of being part of a group of people who take moral values seriously, and this helps them imbibe moral values spontaneously. The present education system has overemphasized the cultivation of the intellect at the cost of the general well-being of humanity. To check this dangerous trend, Vivekananda strongly recommended all-round development of human beings. In one of his lectures he expressed the desire "that all men were so constituted that in their minds all these elements of philosophy, mysticism, emotion, and of work were equally present in full! That is the ideal, my ideal of a perfect man." (CW, vol. II, p. 388)

And the Swami expected that the education systems would be suitably designed to produce such wholesome human beings. Interestingly, the UNESCO report learning to be published in 1972, while defining the aim of education, echoed this same idea. It reads: "The physical, the intellectual, emotional and ethical integration of the individual into a complete man is a broad definition of the fundamental aim of education."

\section{The Education System and the Poor}

So far we have discussed education primarily in the context of the society that already benefits from education. Vivekananda, however, was a genuine friend of the poor and the weak, particularly the helpless masses of India, and he was the first Indian leader who sought a solution to their problems through education. He argued that a nation was advanced to the extent that education and culture reached the masses. Unless there was uniform circulation of national blood all over the body, the nation could not rise. He insisted that it was the duty of the upper classes, who had received their education at the expense of the poor, to come forward and uplift the poor through education and other means. In fact, the Swami's mission was for the poor. He once said, "There must be equal chance for all - or if greater for some and for some less - the weaker should be given more chance than the strong." (Letters, p. 255).

The trend in recent years has been to shift the responsibility for education from the family, religious institutions, private charities and so forth, to public authorities, particularly to the state. Yet, in spite of this shift to the state, education has hardly been successful in reaching the most 
underprivileged people. As they are often victims of malnutrition, poor hygienic conditions and overcrowded housing, they can hardly take advantage of any half-hearted opportunity that is offered. Swami Vivekananda said "Education is the manifestation of the perfection already in man. We want that education by which character is formed, strength of mind is increased, the intellect is expanded, and by which one can stand on one's own feet. So long as the millions live in hunger and ignorance, I hold every man a traitor who, having been educated at their expense pays not the least heed to them. Whatever you think, that you will be. If you think yourselves weak, weak you will be; if you think yourselves strong, strong you will be. If you have faith in all the three hundred and thirty millions of your mythological gods, ... and still have no faith in yourselves, there is no salvation for you. Have faith in yourselves, and stand up on that faith and be strong; that is what we need. Strength, strength it is that we want so much in this life, for what we call sin and sorrow have all one cause, and that is our weakness. With weakness comes ignorance, and with ignorance comes misery. Teach yourselves, teach everyone his real nature, call upon the sleeping soul and see how it awakes. Power will come, glory will come, goodness will come, purity will come, and everything that is excellent will come when this sleeping soul is roused to self-conscious activity.

Vivekananda felt that alienation of the poor of any kind from the masses of society,whether it be alienation through learning, through wealth or through force of arms - weakens the leadership of a country (Datta, 1993). Therefore, for a sustainable regeneration of India, if not for anything else, top priority must be given to educating the masses and restoring to them their lost individuality. They should not only be given education to make themselves self-reliant, but also ideas, moral training and an understanding of their own historical situation so that they can work out their own salvation. Furthermore, they must be given culture, without which there can be no hope for their long-term progress. The Swami was particularly worried about the degradation of women in India. He was emphatic that women must be educated, for he believed that it is the women who mould the next generation, and hence, the destiny of the country. In Vivekananda's educational scheme for India, the uplift of women and the masses received the highest priority.

\section{CONCLUSION}

There have been many changes in the field of education since Swami Vivekananda passed away one hundred years ago, but not as many changes as in other areas of society. One such noticeable change in education is that it is now engaged in preparing human beings for a new type of society, and it is trying to create a new type of human being for it. Interestingly, Swami Vivekananda had envisioned a society with a new type of human being in whom knowledge, action, work and concentration were harmoniously blended, and he proposed a new type of education for achieving this. The right to education for everyone, guaranteed by the Constitution of India, was Vivekananda's dream, but it is still a far cry from its goal. His idea of continual, or lifelong, education, however, has been adopted in many countries already. Moreover, because of the adoption of continuous education in these countries, our idea of what constitutes success and failure has altered, raising new hope for the weak, underprivileged section of these societies - the very people who for various reasons cannot complete their education when they are young. Vivekananda's cry for the uplift of the downtrodden masses, particularly of the longneglected women, has evoked a favourable response from different quarters, but societies tailor education to meet their own needs, thereby often robbing the weak of their freedom to determine their own destiny. Unless radical changes are made in all societies the poor will 
MISHRA

never be able to raise themselves and live better lives with fully developed characters.

VIKRANT MISHRA, PhD, Assistant Professor, Directorate of Distance Education, Kurukshetra University, Kurukshetra, India.

\section{REFERENCE}

Advaita Ashram (1989). Complete Work of Swami Vivekananda (Vol. I-X). Kolkata: Advaita Ashram Publication.

Aggarwal, J. C (2002). Theory and principles of education (p.384). New Delhi: Vikas Publishing house.
Chakarborty A. K. (2004). Theory and Principles of Education (p. 574-583). Meerut: Surya Publication

Datta, B. (1993). Swami Vivekananda, patriot-prophet - a study. Calcutta: Nababharat Publication.

Gambhirananda, S. (1996). Yuganayak Vivekananda [Vivekananda, the leader of this era, Vol. 3, p. 52]. Calcutta: Udbodhan Karyalaya Prakashan.

Krishnamurti, J. (1912). Education as service (p. 86). Adyar, Madras: Theosophical Publishing Society.

Vivekananda, S. (2008). My Idea of Education (p.851). Kolkata: Advaita Ashrama Publication. 